\title{
Factors Leading to Cesarean Section Delivery at Tarakan Hospital, North Kalimantan
}

\author{
Rahmi Padlilah, Ika Yulianti, Ririn Ariyanti \\ Department of Midwifery, University of Borneo Tarakan
}

\section{ABSTRACT}

Background: The increase in cesarean section delivery requires attention. Mortality and morbidity rates for mother and fetus increase in line with the increase in cesarean section delivery. This study aimed to analyze the factors affecting the delivery of cesarean section.

Subjects and Method: This was an analytical observational study with a case-control design. The study was conducted at Tarakan Hospital, North Kalimantan, from 2018 to 2020. There were 200 study subjects as the sample of this study that was selected by purposive sampling. The dependent variable was cesarean section delivery. The independent variables were parity, age, history of the disease, medical indications, and ANC history. This study used medical records to collect the data with multiple logistic regression analysis.

Results: Cesarean section delivery increased with multiparous $(\mathrm{OR}=1.26 ; 95 \% \mathrm{CI}=1.67$ to $7.45 ; \mathrm{p}=0.001)$, age $<20$ and $\geq 35$ years $(\mathrm{OR}=$
1.51; $95 \% \mathrm{CI}=2.12$ to 9.66; $\mathrm{p}<0.001$ ), high-risk pregnancies such as diabetes mellitus, anemia, hypertension and preeclampsia $(\mathrm{OR}=1.50 ; 95 \%$ $\mathrm{CI}=2.12$ to $9.52 ; \mathrm{p}<0.001)$, medical indications $(\mathrm{OR}=1.37 ; 95 \% \mathrm{CI}=1.82$ to $8.57 ; \mathrm{p}=0.001)$ and complete ANC history $(\mathrm{OR}=0.26 ; 95 \% \mathrm{CI}=0.13$ to $0.56 ; \mathrm{p}=0.001$ ).

Conclusion: Caesarean section delivery increases with multiparous, age $<20$ and $\geq 35$ years, had a history of the disease, medical indications, and a complete ANC history.

Keywords: cesarean section, influencing factors, logistic regression analysis

\section{Correspondence:}

Rahmi Padlilah. University of Borneo Tarakan. Jl. Amal Lama No.1 Tarakan, North Kalimantan. Email: rahmipadlilah@gmail.com. Mobile: +62811538073 .

Cite this as:

Padlilah R, Yulianti I, Ariyanti R (2021). Factors Leading to Cesarean Section Delivery at Tarakan Hospital, North Kalimantan. J Matern Child Health. 06(01): 77-83. https://doi.org/10.26911/thejmch.2021.06.01.o8.

(c) (i) (-) Journal of Maternal and Child Health is licensed under a Creative Commons Attribution-Non Commercial-Share Alike 4.o International License.

\section{BACKGROUND}

Cesarean section or Sectio Caesarea (SC) is the most important surgery in the obstetrics field and its incidence is increasing around the world (Vogel et al., 2015; Benzouina et al., 2016) Benzouina et al., 2016). The incidence of SC varied from 10 to $25 \%$ in developing countries, however, the morbidity and mortality rates for both mother and fetus were reported to increase following the increase of CS action compared to vaginal delivery (Diana and Tipandjan, 2016).

The World Health Organization (WHO) did not recommend all regions in the world to have an $\mathrm{SC}$ rate of more than $15 \%$, it was done to reduce the negative effects of SC actions (WHO, 2015). In Indonesia, the data showed that only about $10 \%$ of pregnant women needed specialist obstetric care and only half of them required SC surgery, but in general, the number of SC deliveries in government hospitals was around 20-25\% while in private hospitals it could reach $30-$ $80 \%$ of the total deliveries (Ayuningtyas et al., 2018). SC surgery had been reported to increase the risk of maternal death up to 10 times compared to vaginal delivery. Other negative effects on mothers that might occur 
include wound infection, puerperal sepsis, bleeding and blood transfusions, anesthesia, pulmonary embolism, intraoperative trauma and fetal injury in the short term and repeated CS in subsequent pregnancies added the risk of uterine rupture, acoustic placenta, and hysterectomy (Chongsuvivatwong et al., 2010). Besides, fetal complications consist of birth asphyxia, transient tachypnea of the newborn, respiratory distress syndrome, sepsis, and soft-tissue injuries (Yang and Sun, 2017).

The increase of cesarean section can be influenced by other factors such as maternal characteristics, other medical indications, or incomplete antenatal care (ANC) examinations. By understanding these various factors, it is hoped that a reduction in the number of caesar deliveries can be realized in Tarakan district, East Kalimantan. Based on the background description, the authors were interested in studying and understanding more about the factors that influence cesarean section delivery at Tarakan Hospital, North Kalimantan.

\section{SUBJECTS AND METHOD \\ 1. Study Design}

This study was an analytical observational study with a case-control design. The study was conducted at Tarakan Hospital, North Kalimantan in 2018 - 2020.

\section{Population and Sample}

The population of this study was all women who gave birth in Tarakan and a sample of 200 mothers giving birth in Tarakan Hospital. This study used a purposive sampling technique to collect the sample.

\section{Study Variables}

The dependent variable was cesarean section delivery. The independent variables were parity, age, history of disease, medical indications, and ANC history.

\section{Operational Definition of Variables} Cesarean section delivery was a delivery process that did not pass through the birth canal and a surgical process was performed. Parity was a condition of giving birth to children, whether alive or dead, but not abortion, regardless of the number of children in the primiparous category if the mother gives birth for the first time and multiparous for mothers who give birth more than 2 times.

Age was the age of the research subjects at the time of data collection was 20- 35 years as reproductive age and $<20$ years and $>35$ years because the ages were too young and too old.

High-risk pregnancy was a body condition experienced by the mother before childbirth or in the pregnancy process that worsens labor conditions (diabetes mellitus, anemia, hypertension, and pre-eclampsia).

Medical indication was a condition that causes a therapy, procedure, or investigation related to delivery with $\mathrm{CS}$, with complications such as abnormal presentation, prolonged labor, fetal distress, umbilical cord prolapse, uterine rupture, hypertension, placental problems.

ANC history is a track record of antenatal care for pregnant women according to standards, namely at least 1 time in TM 1,1 time in TM 2, and 2 times in TM 3 with a complete category if ANC $\geq 4$ times and incomplete if $<4$ times, measured by medical records.

\section{Study Instruments}

The data were analyzed by multiple logistic regression.

\section{Data Analysis}

All variable data was measured by watching the medical record data.

\section{Research Ethic}

Research ethics include informed consent, anonymity, confidentiality, and ethical clearance. The research ethics number is No. 014 / KEPK-RSUD KALTARA / IX / 2020. 


\section{RESULTS}

\section{Sample Characteristics}

The subjects of this study were 200 mothers who gave birth at Tarakan Hospital, North Kalimantan. The frequency distribution of the characteristics of the study subjects showed that almost half of the study subjects with maternal parity were multiparous which were 95 subjects (47.5\%), most of them aged

\section{Table 1. The characteristics of the sampl}

\begin{tabular}{|c|c|c|c|}
\hline Characteristic & Category & Frequency (n) & Percentage (\%) \\
\hline \multirow{2}{*}{ Parity } & Primiparous & 105 & 52.5 \\
\hline & Multiparous & 95 & 47.5 \\
\hline \multirow[t]{2}{*}{ Age } & 20 and 35 years & 93 & 46.5 \\
\hline & $<20$ and $\geq 35$ years & 107 & 53.5 \\
\hline \multirow{2}{*}{ Medical Indication } & No & 100 & 50.0 \\
\hline & Yes & 100 & 50.0 \\
\hline \multirow{2}{*}{ ANC history } & Complete & 107 & $53 \cdot 5$ \\
\hline & Incomplete & 93 & 46.5 \\
\hline
\end{tabular}

$<20$ and $\geq 35$ years as many as 107 subjects (53.5\%). Almost half of the study subjects had a history of disease were 91 subjects (45.5\%). Half of all the study subjects had medical indications, as many as 100 (50.0\%). The last characteristic was the ANC description, most of the study subjects with complete ANC history were 107 (53.5\%).

\section{The result of bivariate analysis}

Based of Table 2 Analysis of the relationship between parity and cesarean section delivery $\mathrm{p}$-value $<0.001$ and $\mathrm{OR}=4.33$, it could be interpreted that there was a significant relationship. Mothers with multiparity were 4.33 times more likely to use cesarean section delivery than mothers with primiparous. The Table 2. Bivariate analysis analysis of the relationship between age and cesarean section delivery with $\mathrm{p}$-value $<0.001$ and $\mathrm{OR}=5.72$, it could be interpreted that there was a significant relationship. Mothers who gave birth at the age of $<20$ and $\geq 35$ years had 5.72 times more likely to have a cesarean section delivery compared to mothers with age 20 and 35 years.

\begin{tabular}{|c|c|c|c|c|c|c|c|c|}
\hline \multirow{3}{*}{ Group of Variables } & \multicolumn{4}{|c|}{$\begin{array}{c}\text { Cesarean Section } \\
\text { Delivery }\end{array}$} & \multirow{2}{*}{\multicolumn{2}{|c|}{ Total }} & \multirow{3}{*}{$\mathbf{O R}$} & \multirow{3}{*}{$\mathbf{p}$} \\
\hline & \multicolumn{2}{|c|}{ No } & \multicolumn{2}{|c|}{ Yes } & & & & \\
\hline & $\mathbf{N}$ & $\%$ & $\mathbf{N}$ & $\%$ & $\mathbf{N}$ & $\%$ & & \\
\hline \multicolumn{9}{|l|}{ Parity } \\
\hline Primiparous & 70 & 66.7 & 35 & $33 \cdot 3$ & 100 & 100 & 4.33 & $<0.001$ \\
\hline Multiparous & 30 & 31.6 & 65 & 68.4 & 100 & 100 & & \\
\hline \multicolumn{9}{|l|}{ Age } \\
\hline 20 and 35 years & 69 & 71.1 & 28 & 28.9 & 97 & 100 & 5.72 & $<0.001$ \\
\hline $\begin{array}{l}<20 \text { and } \geq 35 \text { years } \\
\text { Medical indications }\end{array}$ & 31 & 30.1 & 72 & 69.9 & 103 & 100 & & \\
\hline No & 62 & 62.0 & 38 & 38.0 & 100 & 100 & 2.66 & 0.001 \\
\hline Yes & 38 & 38.0 & 62 & 62.0 & 100 & 100 & & \\
\hline \multicolumn{9}{|l|}{ ANC history } \\
\hline Complete & 35 & 32.7 & 72 & $67 \cdot 3$ & 107 & 100 & 0.21 & $<0.001$ \\
\hline Incomplete & 65 & 69.9 & 28 & 30.1 & 93 & 100 & & \\
\hline
\end{tabular}

Analysis of the relationship between medical indications and cesarean section delivery with a value of $\mathrm{p}=0.001$ and $\mathrm{OR}=$ 2.66, it could be interpreted that there was a 
significant relationship. Mothers who gave birth with medical indications were 2.66 times more likely to have a cesarean section delivery than women who gave birth without any medical indication.

Analysis of the relationship between ANC history and cesarean section delivery with $\mathrm{p}$-value $<0.001$ and $\mathrm{OR}=0.21$, so it can be interpreted that there was a significant relationship. Mothers who had a complete ANC history were 0.21 times more likely to use cesarean section delivery than those who had an incomplete ANC history.

Bivariate analysis aimed to see the relationship between the independent variables (parity, age, history of the disease, medical indications, and ANC overview) and the dependent variable (cesarean section delivery). The results of the bivariate analysis with the chi-square test were:

\section{The result of multilevel analysis}

The results of multivariate analysis showed that there is a relationship of parity with sexo sesaria childbirth. Multipara maternity mothers increased by 1.26 times to perform section cesarea delivery compared to maternity mothers with primipara parity $(\mathrm{OR}=1.26 ; \mathrm{p}=0.001)$. The relationship of age with section cesarea childbirth. Mothers aged $<20$ and $\geq 35$ years of age increased 1.51 times to perform section sesaria delivery compared to maternity mothers aged 20 and 35 years $(\mathrm{OR}=1.51 ; \mathrm{p}<0.001)$. The relationship of high-risk pregnancy with sexo sesaria childbirth. Mothers with high-risk pregnancies increased 1.50 times to perform sexo sesaria delivery compared to mothers who did not have high risk pregnancies $(\mathrm{OR}=1.50$; $\mathrm{p}$ $<0.001)$. The relationship of medical indications with the delivery of section cesarea. Mothers with medical indications increased 1.37 times to perform section cesarea delivery compared to maternity mothers with no medical indication $(\mathrm{OR}=1.37 ; \mathrm{p}=0.001)$. The relationship of the ANC's image with the delivery of section cesarea. Mothers with a complete ANC picture dropped by 0.26 (3.85) times to perform sexist childbirth section cesarea compared to maternity mothers who had incomplete ANC images $(\mathrm{OR}=0.26 ; \mathrm{p}=0.001)$.

Table 3 The Results of multivariate analysis

\begin{tabular}{lcccc}
\hline \multirow{2}{*}{ Cesarean Section Delivery } & \multirow{2}{*}{ OR } & \multicolumn{2}{c}{ 95\% CI } & \multirow{2}{*}{ p } \\
\cline { 3 - 4 } & & Lower limit & Upper limit & 0.001 \\
Parity (multiparous) & 1.26 & 1.67 & 7.45 & $<.66$ \\
Age (<20 and $\geq 35$ years) & 1.51 & 2.12 & 6.76 & 0.001 \\
Medical Indications (yes) & 1.37 & 1.33 & 0.56 & 0.001 \\
ANC history (complete) & 0.26 & 0.13 & \\
N observation= 200 & & & \\
-2 log likelihood=177.16 & & & \\
Nagelkerke $\mathrm{R}^{2}=0.53$ & & & \\
\hline
\end{tabular}

\section{DISCUSSION}

\section{The relationship between parity and cesarean section delivery}

The results showed that there was a relationship between parity and cesarean delivery. Mulyawati et al. (2011) explained that parity is related to cesarean section delivery. Mothers with multiparity experienced decrease reproductive function, the uterine muscles were too stretched and unable to contract properly so that the possibility of a cesarean section delivery was more likely to perform. Fitzpatrick et al. (2019) also explained that multiparity had a higher rate of postpartum hemorrhage incidences compared to primiparous besides that the majority of families with too many children reduced the family's ability to fulfilled good 
nurses, so it increased the possibility of delivery complications thus caused cesarean section delivery.

\section{The relationship between age and cesarean section delivery}

The results showed that there was a relationship between age and cesarean delivery. Rydahl et al. (2019) explained that the results of this study indicated that age was a significant factor affecting the incidence of cesarean delivery, women under 20 years had reproductive organs which were not yet fully developed and immature mental development so that they were not ready to become mothers and accept their pregnancies. Herstad et al. (2016) explained that a pregnant woman under 20 years and $\geq 35$ years had a quite big risk (complications) of pregnancy such as labor that did not progress, prolonged labor, placenta previa, placental abruption, cephalopelvic disproportion, fetal and birth canal factors so that the reproductive age at 20 to 35 years was the appropriate age for the pregnancy program as an effort to reduce labor complications and the risk of cesarean section delivery.

\section{The relationship between medical indications and cesarean section delivery}

The results showed that there was a relationship between medical indications and cesarean section delivery. Rahman et al. (2015) explained that pregnant women with medical indications increased the risk of cesarean section delivery. Fetal distress, umbilical cord twist, serotinus, twin pregnancy are medical indications for cesarean delivery. Medical indications such as fetal distress caused the fetus to have great pressure (usually used to describe fetal hypoxia with low oxygen levels) which could result in fetal damage if the fetus was not treated immediately so that cesarean section delivery had to carry out immediately. Moreover, routine checkup was also necess- ary to perform to detect early the problem that could occur and to detect medical indications that could cause cesarean section delivery.

The umbilical cord twist as a medical indication for cesarean section delivery because umbilical cord twist could cause asphyxia and had to be treated immediately with cesarean section delivery, besides that the use of ANC services could also be used to reduce the risk of cesarean section delivery without any planning by because the condition of the mother and fetus was not detected early (Jodjana and Suryawan, 2020). This study is also in line with the study by Padlilah and Yulianti (2020) that emergency cesarean section delivery had a 4 times higher chance of neonatal death compared to wellintervened cesarean section delivery.

\section{The relationship between ANC history and cesarean section delivery}

The results showed that there was a relationship between ANC overview and cesarean section delivery. Saad et al. (2016), pregnant women who had antenatal care $\geq 4$ had a lower risk of cesarean section delivery. Pregnant women with a complete ANC overview had higher knowledge than mothers with an incomplete ANC overview. Besides, early detection efforts from health workers could reduce the risk of cesarean section delivery such as anemia which could be prevented by giving Fe tablets, so that it could reduce the risk of cesarean section delivery.

Sinyange et al. (2016), the lack of knowledge of pregnant women about the importance of prenatal visits reduced the complete antenatal services so that mothers were late for examinations that the management of the pregnancy could correspond to the maternal condition, if it is necessary, cesarean delivery could be performed for the mother and baby's health. Kaswa, Rupesinghe, and Longo-Mbenza (2018) explained that one of 
the factors that influenced the delay in providing antenatal services was the lack of knowledge of pregnant women about the benefits of antenatal care for primigravida mothers so that it could reduce the efforts to detect early pregnancy problems both for normal pregnancy planning and cesarean section.

\section{AUTHOR CONTRIBUTION}

Rahmi Padlilah, as the main researcher looking for collecting and processing research data; Ika Yulianti examine the conceptual framework and research methodology.

\section{CONFLICT OF INTEREST}

None.

\section{FUNDING AND SPONSORSHIP}

The source of fund came from the main researcher.

\section{ACKNOWLEDGEMENT}

We thank to Tarakan Hospital, North Kalimantan for giving permission to collect the data.

\section{REFERENCE}

Abebe FE, Gebeyehu AW, Kidane AN, Eyassu GA (2016). Factors leading to cesarean section delivery at Felegehiwot referral hospital, Northwest Ethiopia: A retrospective record review. Reprod Health. 13(1): 1-7. doi: 10.1186/s12978-015-0114-8.

Omar AAA, Anza SHA (2012). Frequency rate and indications of cesarean sections at Prince Zaid Bin Al Hussein Hospital-Jordan. Journal of the Royal Medical Services. 19(1): 82-86. https://doi.org/10.15218/zjms.2018.020.

Ayuningtyas D, Oktarina R, Misnaniarti M, Sutrisnawati NND (2018). Etika kesehatan pada persalinan melalui sectio caesarea tanpa indikasi medis. Media
Kesehatan Masyarakat Indonesia. 14 (1): 9-16. http://dx.doi.org/10.30597/mkmi.v14i1.2110.

Benzouina S, Boubkraoui MEM, Mrabet M, Chahid N, Kharbach A, El-Hassani A, et al. (2016). Fetal outcome in emergency versus elective cesarean sections at Souissi Maternity Hospital, Rabat, Morocco. Pan Afr Med J. 23: 197. https://doi.org/10.11604/pamj.2016.23.197.7401 .

Chongsuvivatwong V, Bachtiar H, Chowdhury ME, Fernando S, Suwanrath C, KorAnantakul O, et al. (2010). Maternal and fetal mortality and complications associated with cesarean section deliveries in teaching hospitals in Asia. $\mathrm{J}$ Obstet Gynaecol Res. 36(1):45-51. doi. 10.1111/j.1447-0756.2009.01100.x.

Diana V, Tipandjan A (2016). Emergency and elective caesarean sections: comparison of maternal and fetal outcomes in a suburban tertiary care hospital in Puducherry. Int J Reprod Contracept Obstet Gynecol. 5(9):3060-5. doi: http://dx.doi.org/10.18203/2320-1770.ijrcog20162985.

Fitzpatrick KE, Kurinczuk JJ, Bhattacharya S, Quigley MA (2019). Planned mode of delivery after previous cesarean section and short-term maternal and perinatal outcomes: A populationbased record linkage cohort study in Scotland. PLoS Med. 16(9): e1002913. https://doi.org/10.1371/journal.pmed.1002913.

Herstad L, Klungsøyr K, Skjærven R, Tanbo T, Forsén L, Åbyholm T, et al. (2016). Elective cesarean section or not? Maternal age and risk of adverse outcomes at term: A population-based registry study of low-risk primiparous women. BMC Pregnancy Childbirth. 16(1): 1-11. doi: 10.1186/s12884-016-1028-3.

Jodjana C, Suryawan IWB (2020). Hubungan jenis persalinan dengan kejadian 
asfiksia neonatorum di ruang perinatologi dan Neonatal Intensive Care Unit (NICU) RSUD Wangaya Kota Denpasar. Intisari Sains Medis. 11(1): 327331. doi: 10.15562/ism.v11i1.537.

Kaswa R, Rupesinghe GFD, Longo-Mbenza B (2018). Exploring the pregnant women's perspective of late booking of antenatal care services at Mbekweni Health Centre in Eastern Cape, South Africa. Afr J Prim Health Care Fam Med. 10(1): e1-e9 doi: 10.4102/phcfm.v10i1.1300.

Mascarello KC, Horta BL, Silveira MF (2017). Maternal complications and cesarean section without indication: systematic review and meta-analysis. Rev Saude Publica. 51: 105. doi: 10.11606/S15188787.2017051000389.

Mulyawati (2011). Factors associated with Cesarean Section, a cross sectional study. Jurnal Kesehatan Masyarakat. 1: 15-24. http://journal.unnes.ac.id/index.php/kemas.

Rahman M, Shariff AA, Shafie A, Saaid R, Tahir RM (2015). Caesarean delivery and its correlates in Northern Region of Bangladesh: Application of logistic regression and cox proportional hazard model. J Health Popul Nutr. 33(1): 111. doi: 10.1186/s41043-015-0020-2.

Rydahl E, Declercq E, Juhl M, Maimburg RD (2019) Cesarean section on a riseDoes advanced maternal age explain the increase? A population registerbased study. PLoS ONE. 14(1): eo210655. https://doi.org/10.1371/journal.pone.0210655.

Saad G, DeJong J, Terreri N, Méndez, Jamie
Perin MCR, Vaz L, et al. (2016). Patterns and determinants of antenatal care utilization: Analysis of national survey data in seven countdown countries. J Glob Health. 6(1). doi: 10.7189/jogh.06.010404.

Sinyange N, Sitali L, Jacobs C, Musonda P, Michelo C (2016).Factors associated with late antenatal care booking: population based observations from the 2007 Zambia demographic and health survey. Pan Afr Med J. 25: 109. doi: 10.11604/pamj.2016.25.109.6873.

Padlilah R, Yulianti I (2020). Comparison of infant complication between emergency and caesarean sections: A meta-analysis. J Matern Child Health. 5(2): 200-205. https://doi.org/10.26911/thejmch.2020.05.02.10.

Vogel JP, Betrán AP, Vindevoghel N, Souza JP, Torloni MR, Zhang J, et al. (2015). Use of the robson classification to assess caesarean section trends in 21 countries: A secondary analysis of two WHO multicountry surveys. Lancet Glob Health. 3(5): e260-70. doi: 10.1016/S2214-109X(15)70094-X.

World Health Organization (2015). WHO recommendations on health promotion interventions for maternal and newborn health. World Health Organization Offset Publication.

Yang XJ, Sun SS (2017). Comparison of maternal and fetal complications in elective and emergency cesarean section: a systematic review and meta-analysis. Arch Gynecol Obstet. 296(3): 503-512. doi: 10.1007/s00404-0174445-2. 